\title{
Renewable sources of electricity in the Mazovia region
}

\section{Zbigniew Cieszkowski}

\begin{abstract}
The article discusses the development of renewable sources of electricity in the Mazovia region. The analysis focuses on the 2007-2017 period, making use of an updated 2014 study by the Mazovian Office for Regional Planning - Rozwój energetyki opartej na źródłach odnawialnych w województwie mazowieckim - stan i wyzwania [The development of renewable energy sources in Mazovia - achievements and challenges]. The analytical part of the paper is preceded by information on the identified assets of renewable energy sources (RES) in the region and which parts of Mazovia are best suited for the development thereof. The legal conditions of exploiting RES are briefly discussed along with the resulting spatial planning and organizational activities of the Regional Government of Mazovia and local (municipal) governments. Statistical data is analyzed, with particular focus on information obtained from the Polish Central Statistical Office (GUS) and energy companies. Finally, the production and use of energy in Mazovia is set against other Polish regions and the development of renewable sources of electricity is discussed in the context of RES connected to the national energy grid.
\end{abstract}

Key words: renewable energy sources (RES), RES potential, climate and energy policy, RES support, installed power, National Power System (KSE), wind power, biomass, biogas, hydropower, solar power, geothermal energy, prosumer

\section{Introduction}

The European Union's modern, multifaceted climate and energy policy has been implemented in member countries, resulting in an organized, institutionalized support for the development and use of renewable energy sources. Formally, the policy was the result of the adoption in December 2008 of various documents, agreements and legal acts named the "Climate and energy package". The key goal of the package is to achieve the $3 \times 20$ targets: a 20\% cut in greenhouse gas emissions (from 1990 levels), a 20\% improvement in energy efficiency and a $20 \%$ share of EU energy from renewables. Poland, as a member of the EU since 2004, has taken an active part in implementing the European climate and energy policy through legal, spatial planning and organizational activities as well as investments - on the national, regional and local level.

In Poland, a system of support for renewable sources of electricity (RSE) based on a crucial legal act on energy [Ustawa z dnia 10 kwietnia 1997 r. Prawo energetyczne] was prepared in 20062010, resulting in a dynamic growth of RSE. In 2010-2012 the production of renewable energy was profitable due to national subventions in the form of "green certificates". Since 2013 the conditions have rapidly grown worse, as the system of support for RSE turned out to be overregulated: the rapid increase in production of electricity from wind and biomass resulted 
in overproduction which entailed a fall in the prices of green certificates. In consequence, the production of renewable energy became much less profitable and a slackening followed in the sectors of co-firing and the use of biomass in large installations. The wind energy sector also saw a significant decrease in profitability.

In effect, in 2015 the national government overhauled the system of support for renewable energy sources (RES) and limited the legal possibilities of further expansion of high-capacity wind energy installations, shifting the energy policy towards protection of the Polish coal industry. This resulted in the passing of two key acts: one changing the regulations concerning the RES market [Ustawa z dnia 22 czerwca 2016 r. o zmianie ustawy o odnawialnych źródłach energii oraz niektórych innych ustaw], the other concerning the places where wind energy installations can be built [Ustawa $z$ dnia 20 maja 2016 r. o inwestycjach w zakresie elektrowni wiatrowych].

Mazovia's regional climate and energy policy is included in the regional development policy, as expressed in the region's main strategic and spatial planning documents [Strategia rozwoju województwa mazowieckiego do roku 2020 (aktualizacja) - 2006, Strategia rozwoju województwa mazowieckiego do 2030 roku. Innowacyjne Mazowsze - 2013, Plan zagospodarowania przestrzennego województwa mazowieckiego - 2004, 2014]. The regional government also fulfills its legal obligations in the field of energy and fuel supply planning by issuing opinions on relevant municipal documents, energy companies' development plans and their applications for concessions from the Energy Regulatory Office (Urząd Regulacji Energetyki).

The regional government has authorized the Mazovian Office for Regional Planning (MBPR) to fulfill the abovementioned duties, as well as gather data concerning energy, conduct relevant studies and prepare plans. The Mazovian Office for Regional Planning is an organizational unit of the regional government, supervised by the Management Board of the Mazovia Region. Among the studies conducted by the Office concerning RES in Mazovia is an extensive monograph prepared in 2015 [Rozwój energetyki opartej na źródłach odnawialnych w województwie mazowieckim]. Its goal was to present selected conditions (mainly legal and formal ones) for the development of renewable energy in Mazovia in 2007-2013 when RES were supported with EU funds, as well as the challenges to and possibilities of development of RES in the 2014-2020 financial perspective. The study also noted that it was to be a compendium of knowledge concerning renewable energy, knowledge necessary for the implementation of the regional government's tasks in the fields of development policy and spatial planning.

Poland's obligation to the EU is to achieve by 2020 a 15\% share of energy from RES in its total energy consumption. The national plan concerning renewable energy [Krajowy plan działania w zakresie energii ze źródet odnawialnych] provides details as to the target shares of RES in specific types of energy: $19.13 \%$ in the case of electric energy, $17.05 \%$ in the case of heating and cooling, $10.14 \%$ in the case of transport fuels. Mazovia's contribution to the national goals will be important, as the region plays a crucial role in Poland's economy, including the production and use of electric energy. It also has a significant RES potential. The 2015 study on RES in Mazovia estimates that by 2020 electric energy from renewables available for use in Mazovia could cover $20 \%$ of the expected demand for electricity. This 
would fulfill the national goal on a regional scale, but achieving such a level requires several crucial conditions to be met on the national and regional level, the most important one being an effective and synergetic system of national economic, organizational and legal support for RES. Another crucial condition is the development of modern technology in the entire energy sector and the implementation of energy planning requirements by regional and local governments.

The main goals of the analyses in this article are:

- to identify the level of development of renewables-based energy sources and set it against the diagnosed assets of natural energy and the total level of energy production and use in Mazovia,

- to assess the extent to which the Mazovian regional and local governments have implemented their legal obligations concerning energy planning,

- to assess the risks and opportunities resulting from the changes to the EU's energy and climate policy and the Polish renewable energy policy.

\section{Forecasts concerning RES exploitation in Mazovia}

The exploitation of renewable energy sources present in Mazovia has been the subject of a number of studies, the most important of which was a program adopted by the Regional Assembly of Mazovia in October 2006 [Program możliwości wykorzystania odnawialnych źródeł energii dla województwa mazowieckiego]. The main goals of the Program were:

- to assess RES assets and identify the possibilities of their exploitation, taking into account areas where such possibilities are limited due to ecological aspects,

- to identify areas with favorable conditions for the development of renewable energy production.

Areas with favorable conditions for the development of wind energy were defined as those where the average annual wind speed exceeds $4 \mathrm{~m} / \mathrm{s}$. Such conditions allow for 1250 $\mathrm{kWh}$ of energy to be obtained per square meter per year and can be found in over $50 \%$ of Mazovia (Fig. 1). However, as investments in wind energy were implemented, a significant share of the high-capacity wind farms was built outside this area. The Program assessed the total amount of electric energy which may be obtained from wind, taking into account environmental limitations, at around $100 \mathrm{MW}$. This, however, turned out to be significantly below the actual potential, as by the end of 2017 the combined installed wind power capacity in Mazovia summed up to 386 MW. In 2013-2014 the Mazovian Office for Regional Planning conducted a survey among electric power companies which showed that the permissions for connection of wind farms to distribution networks summed up to $640 \mathrm{MW}$ and those to transmission networks to $240 \mathrm{MW}$. This means that at a time of peak interest in RES development planning, investors were interested in building wind power plants in Mazovia significantly exceeding the potential diagnosed as possible to be exploited. In practice, of the $880 \mathrm{MW}$ of planned connections, only 386.158 MW were realized. 
Areas with favorable conditions for the development of energy from solid biomass were defined as those with the highest potential for production of straw and wood. The amount of thermal energy which may be obtained was assessed, but the possibilities of producing electric energy were not analyzed. An analogical approach was adopted in the case of various forms of biogas. However, in practice the diagnosed assets of biomass are in part being used to produce electric energy through co-incineration and separate combustion. Part of the agricultural biomass is also being used after being transformed into biogas. Therefore, Figure 2 illustrates the areas with favorable conditions for the use of biomass and areas where biomass and biogas electric energy sources were installed.

The Program also didn't assess the electric energy potential of natural assets of geothermal and solar energy.

Mazovia has limited possibilities for the development of hydroenergy. This is due to the low energy values of rivers in lowland areas. The high cost of building dams and their negative impact on the environment mean that large hydroelectric power plants are not planned in the region. Only in the field of small installations is there potential for growth, with the best conditions in the valleys of the Skrwa Prawa, Wkra, Orzyca, Liwiec, Radomka and Iłżanka rivers (Fig. 3). An appraisal of the energy potential of rivers in the region assessed the total capacity of ecologically rational hydroelectric power plants at $40 \mathrm{MW}$. At the end of 2017 this assessment appears to have been accurate, which means that Mazovia's rivers still hold around $20 \mathrm{MW}$ of power available to be exploited.

Two other studies relevant to providing a diagnosis of the regional RES assets were conducted by the Institute for Renewable Energy [Instytut Energetyki Odnawialnej]: an assessment of the renewable energy potential of Polish regions [Określenie potencjału energetycznego regionów Polski w zakresie odnawialnych źródeł energii ...] and a countrywide plan for the development of RES micro-installations by 2030 [Krajowy plan rozwoju mikroinstalacji i odnawialnych źródet energii do roku 2030]. In the first one an element of information relevant from the point of view of Mazovia was an assessment of the potential of three renewable sources of electricity. The economic potential was defined as the amount of energy which can be obtained per year from the regional assets of RES through the use of available technology, taking into account economic viability as well as spatial and ecological limitations. In the case of wind energy, the potential was estimated at $300 \mathrm{MW}$ (the lowest among Polish regions) for high-capacity installations and around $70 \mathrm{MW}$ for low-capacity prosumer ones. The potential of agricultural biogas was assessed at $80 \mathrm{MW}$.

The plan for the development of RES micro-installations focuses on prosumers. RES micro-installations are defined as sources of electricity capable of generating no more than 40kW: micro solar panel systems, wind turbines, biogas plants, cogeneration systems for bioliquids. The analyses conducted allowed for an assessment of the total national potential of electric prosumer installations: from $800 \mathrm{MW}$ in 2016 to 16,000 MW in 2030. In the case of Mazovia: from $90 \mathrm{MW}$ in 2016 to $440 \mathrm{MW}$ in 2020. However, by the end of 2016 the total capacity of active micro-installations in 2016 in Mazovia was in fact only 6.6 MW and 16.384 


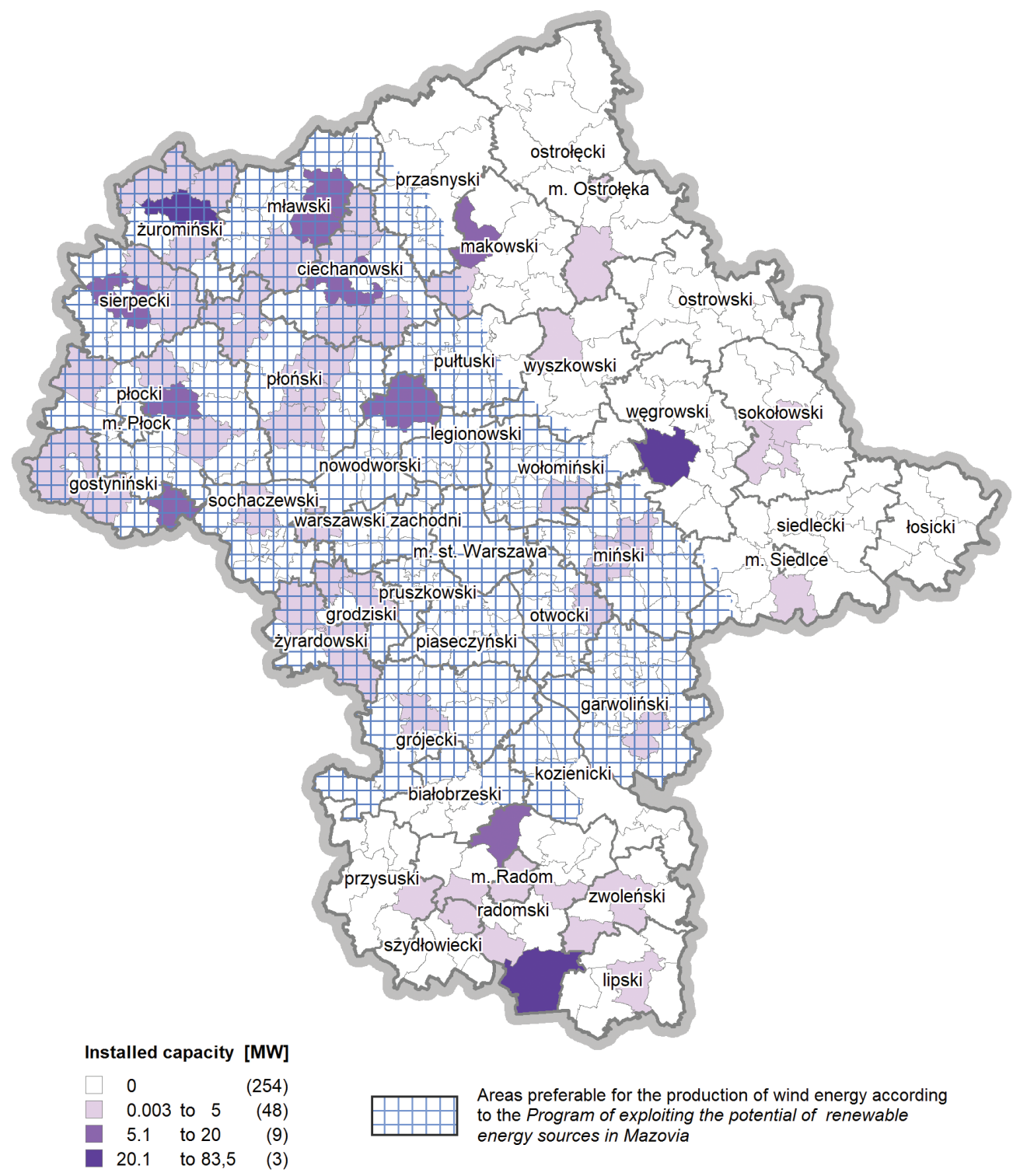

Fig. 1. The installed capacity of renewable energy sources (wind energy) connected to the national electricity grid in the municipalities of the Mazovia region as of 31.12.2017

Source: own work based on the Program możliwości wykorzystania odnawialnych źródeł energii dla województwa mazowieckiego [Program of exploiting the potential of renewable energy sources in Mazovia] and data from energy companies 


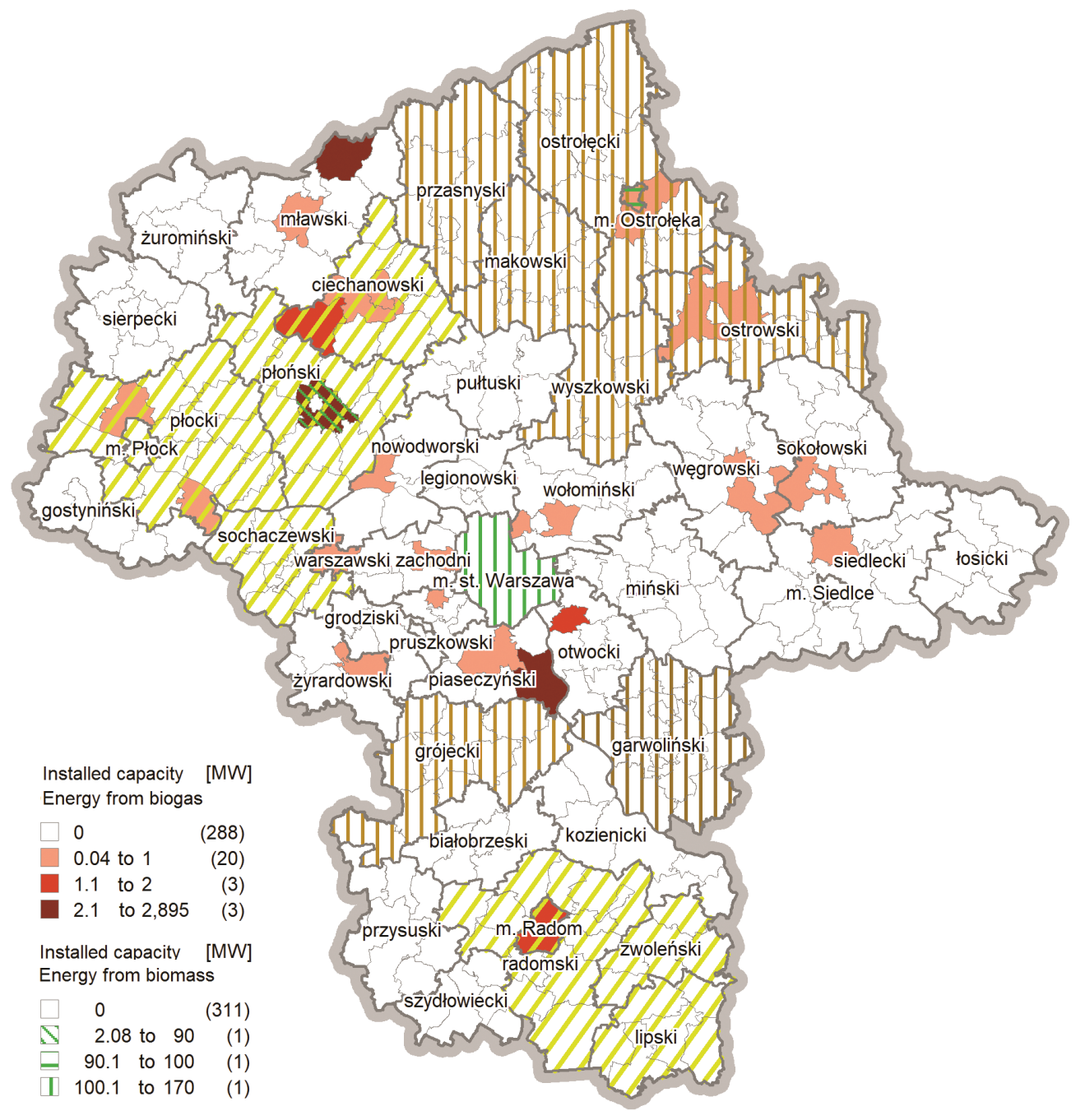

11 Areas preferable for the production of renewable energy from straw

Ш\|\| Areas preferable for the production of renewable energy from wood biomass

Fig. 2. The installed capacity of renewable energy sources (biomass and biogas) connected to the national electricity grid in the municipalities of the Mazovia region as of 31.12.2017

Source: own work based on the Program możliwości wykorzystania odnawialnych źródeł energii dla województwa mazowieckiego [Program of exploiting the potential of renewable energy sources in Mazovia] and data from energy companies 


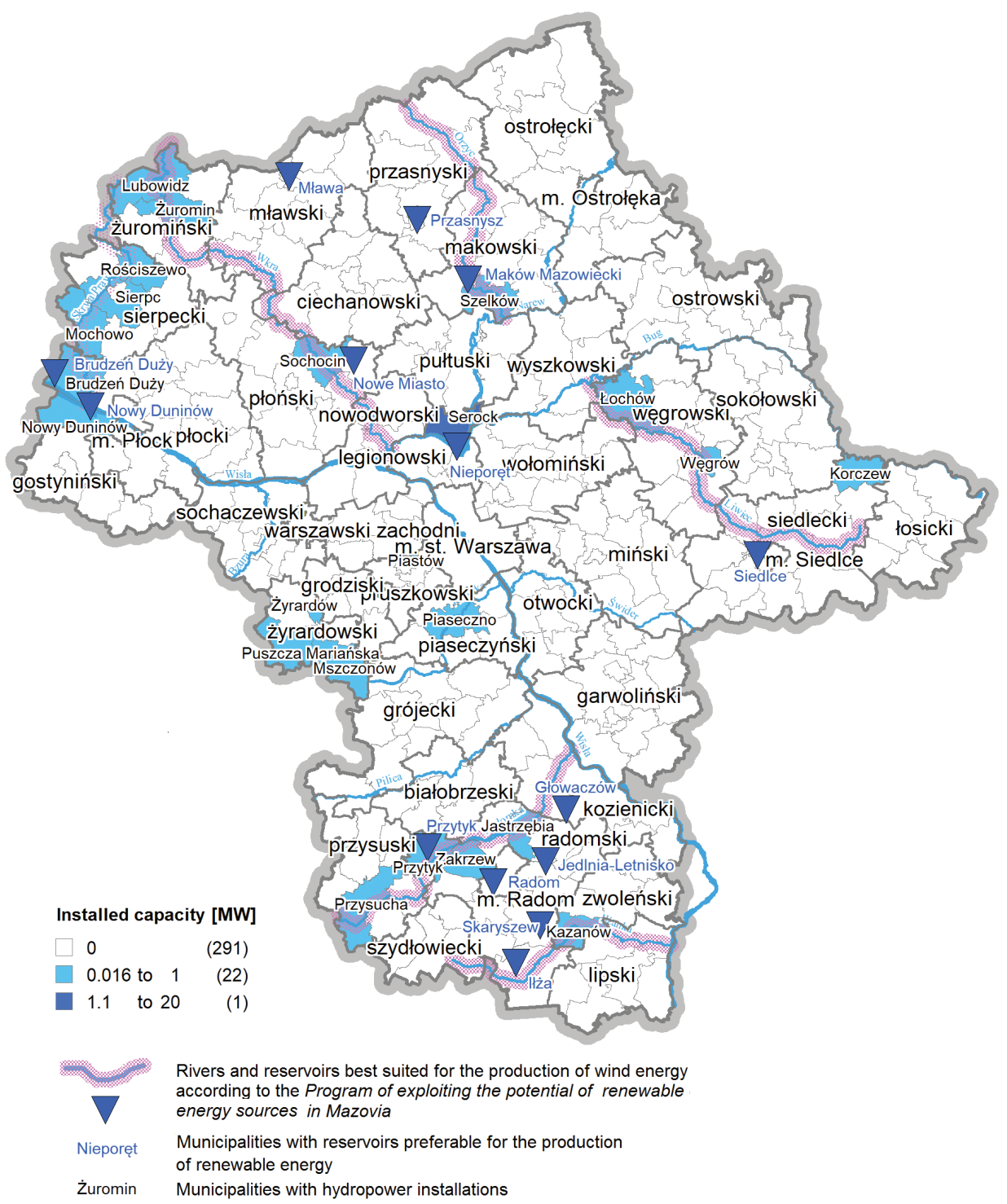

Fig. 3. The installed capacity of renewable energy sources (waterpower) connected to the national electricity grid in the municipalities of the Mazovia region as of 31.12.2017

Source: own work based on the Program możliwości wykorzystania odnawialnych źródeł energii dla województwa mazowieckiego [Program of exploiting the potential of renewable energy sources in Mazovia] and data from energy companies 
MW in 2017. This shows that the implementation of the plan for the development of microinstallations is taking place much slower than the document had assumed. In fact, only solar panels are growing in number. Other types of micro-installations are barely present.

\section{Organizational activities of the Regional Government of Mazovia for the development of RES in 2007-2017}

The Regional Government of Mazovia implemented the Regional Operational Program of the Mazovia Region 2007-2013 (RPO WM 2007-2013), thus providing financial support for investments in exploiting RES. Such actions were implemented as part of Priority IV of the RPO WM 2007-2013: The environment, risk prevention, energy, goal 4.3: Preventing air pollution, energy production. The specific detailed goal was: Building and modernizing infrastructure for the production of electric energy and heating, increasing the amount of energy from renewable sources and high-efficiency cogeneration. In 2007-2015, as the RPO WM 2007-2013 was being implemented, 102 projects serving to realize this goal were carried out, of which 90 consisted of thermal efficiency improvement and using RES for heating, and only $12(11.8 \%)$ focused on producing electricity - mainly through harnessing wind power (7 projects) and, in individual cases, from solar power (photovoltaic installations) and combined heat and power units.

The above-mentioned projects resulted in providing a total electric capacity of $17 \mathrm{MW}$, i.e. $3.5 \%$ of the installed power from RES connected to the national electricity grid in 2007-2015. From a spatial point of view (Fig. 4), all 102 investments in exploiting RES and improving energy efficiency were implemented in 77 municipalities $(24.5 \%$ of the total number of Mazovian municipalities).

The current Regional Operational Program of the Mazovia Region 2014-2020 (RPO WM 2014-2020) provides support for activities contributing to the transition to a low-emission economy, greater use of renewable energy sources and improving energy efficiency. Mazovia received 324 million EUR for such support.

The development goals for the RES sector concern two activities within Priority Axis IV - Transition towards a low-emission economy. Activity 4.1 is focused on increasing the share of RES in the total production of electricity and heat. Within this activity, support is provided to projects dealing with the development of infrastructure for the production and distribution of energy from renewable sources. Activity 4.2. is oriented towards increasing energy efficiency in the public and housing sectors. Support is provided to projects improving thermal efficiency which should also include elements of RES and combined heat and power generation.

According to data from the Mazovian Unit of EU Program Implementation, by 12.03.2018, 18 contracts were signed for the implementation of projects within Activity 4.1 and 101 contracts within Activity 4.2. In terms of the amount of funds used, the EU funds provided for the 119 projects amount to $80.26 \%$ of the total sum of EU funds allocated to the region for such purposes. 


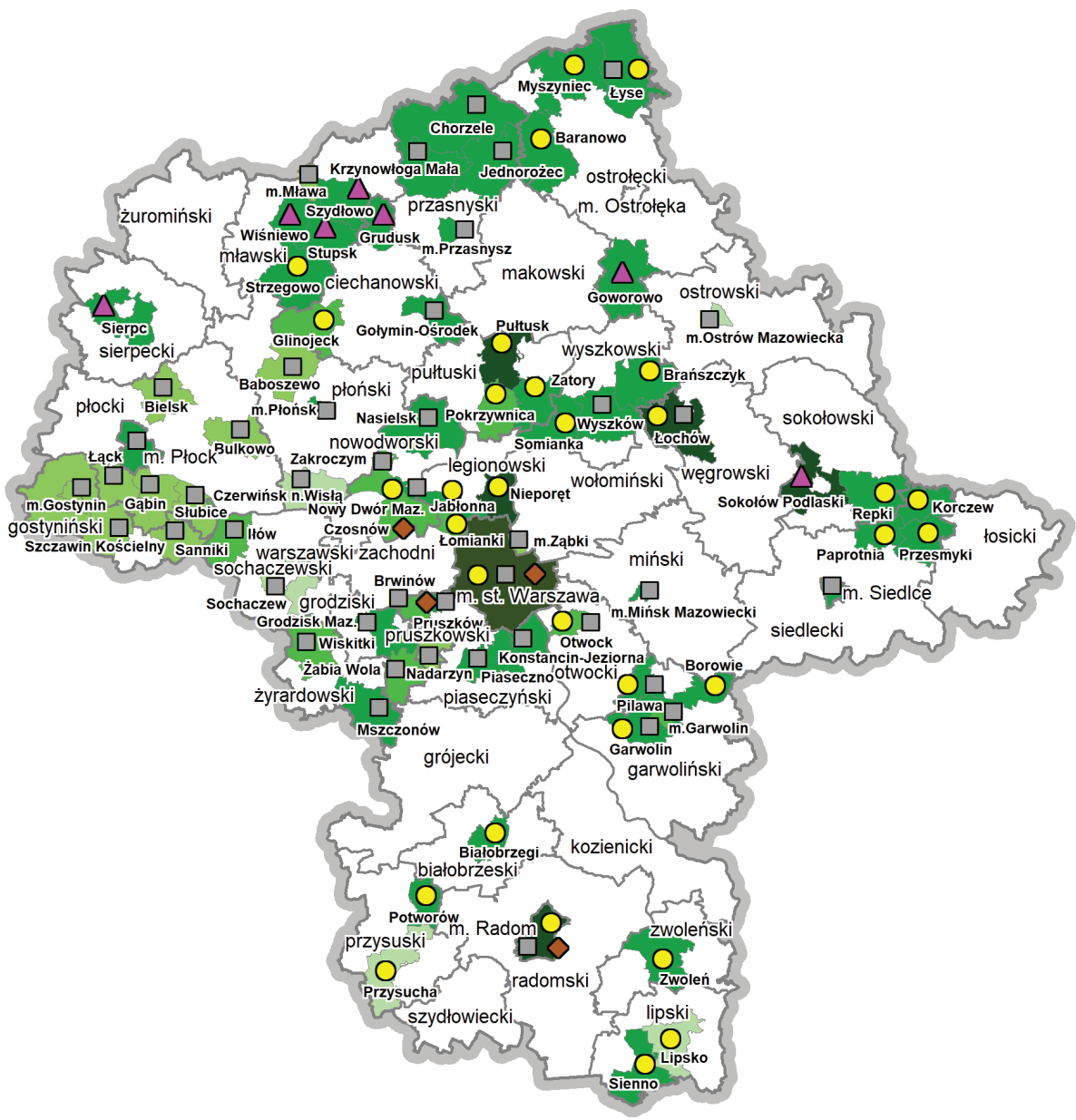

Amount of financial aid from EU funds 1 do 200000 200001 do 500000 500001 do 1000000 1000001 do 5000000 5000001 do 7792376 21028552 do 21028552
Investments into exploiting individual energy types:

$$
\begin{array}{ll}
\bigcirc & \text { sun } \\
\triangle & \text { wind } \\
\text { sun or geothermal - with thermal } \\
\text { efficiency improvement } \\
\text { sun, geothermal or wind - with combined } \\
\text { heat and power units }
\end{array}
$$

Fig. 4. Investments into exploiting RES implemented as part of the RPO WM 2007-2013 Source: own work by MBPR based on data from The Mazovian Unit of EU Program Implementation (Mazowiecka Jednostka Wdrażania Programów Unijnych) 


\section{Activities of the Regional Government of Mazovia in fuel and energy supply planning in the region}

Energy planning tasks are assigned to regional governments by the Polish Energy Law [Ustawa z dnia 10 kwietnia 1997 r. Prawo energetyczne]. They are realized mainly through issuing opinions on municipalities' and energy companies' energy planning documents and on applications for concessions in the field of power supply. Since 2007 these tasks are realized by the Mazovian Office for Regional Planning, in accordance with a decision by the Management Board of the Mazovia Region. In 2007-2017, a total of 879 opinions were issued (Fig. 5).

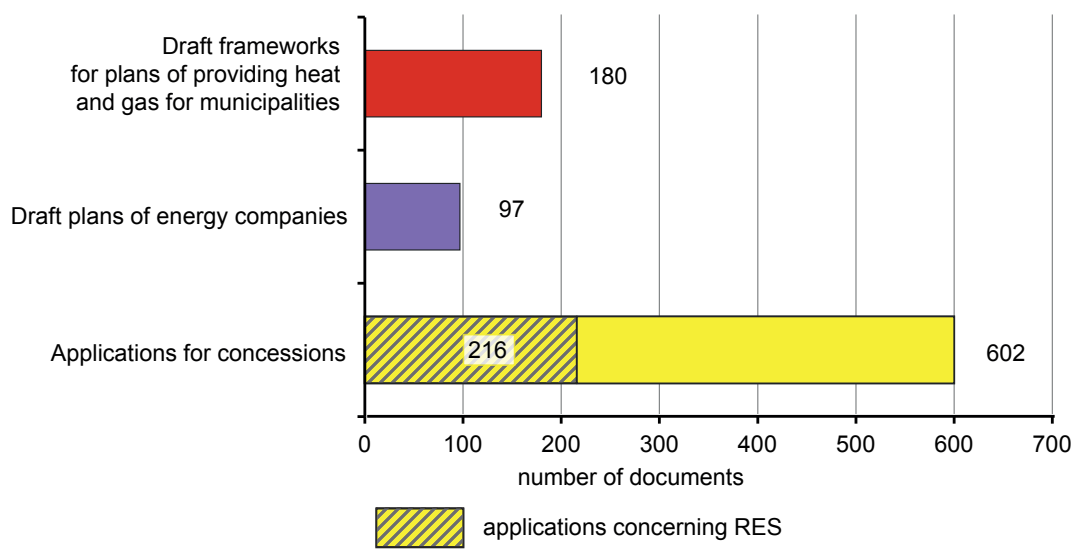

Fig. 5. Documents for which opinions were issued by the Management Board of the Mazovia Region in 2007-2017

Source: own work by MBPR

\section{Municipal governments' organizational and spatial planning activities for the development of RES in 2007-2017}

During the ten years in question, the municipalities in Mazovia prepared energy planning documents, in accordance with the requirements of the Polish Energy Law [Ustawa z dnia 10 kwietnia 1997 r. Prawo energetyczne]. By the end of 2017, slightly more than half (163 of 314) municipal governments had prepared frameworks for plans of providing heat, electricity and gas. 17 of these documents concerned parts of Warsaw.

As can be seen in Figure 6, the possession of a completed framework increases the chances of developing renewable energy sources. Of the 163 municipalities with such a document, 146 (89.6\%) have installations for producing electricity from RES while 17 (10.4\%) do not. However, the document is not a key factor, taking into account that of the 274 municipalities with renewable sources of electricity, $146(52.9 \%)$ have prepared a framework and $128(47.1 \%)$ have not. 


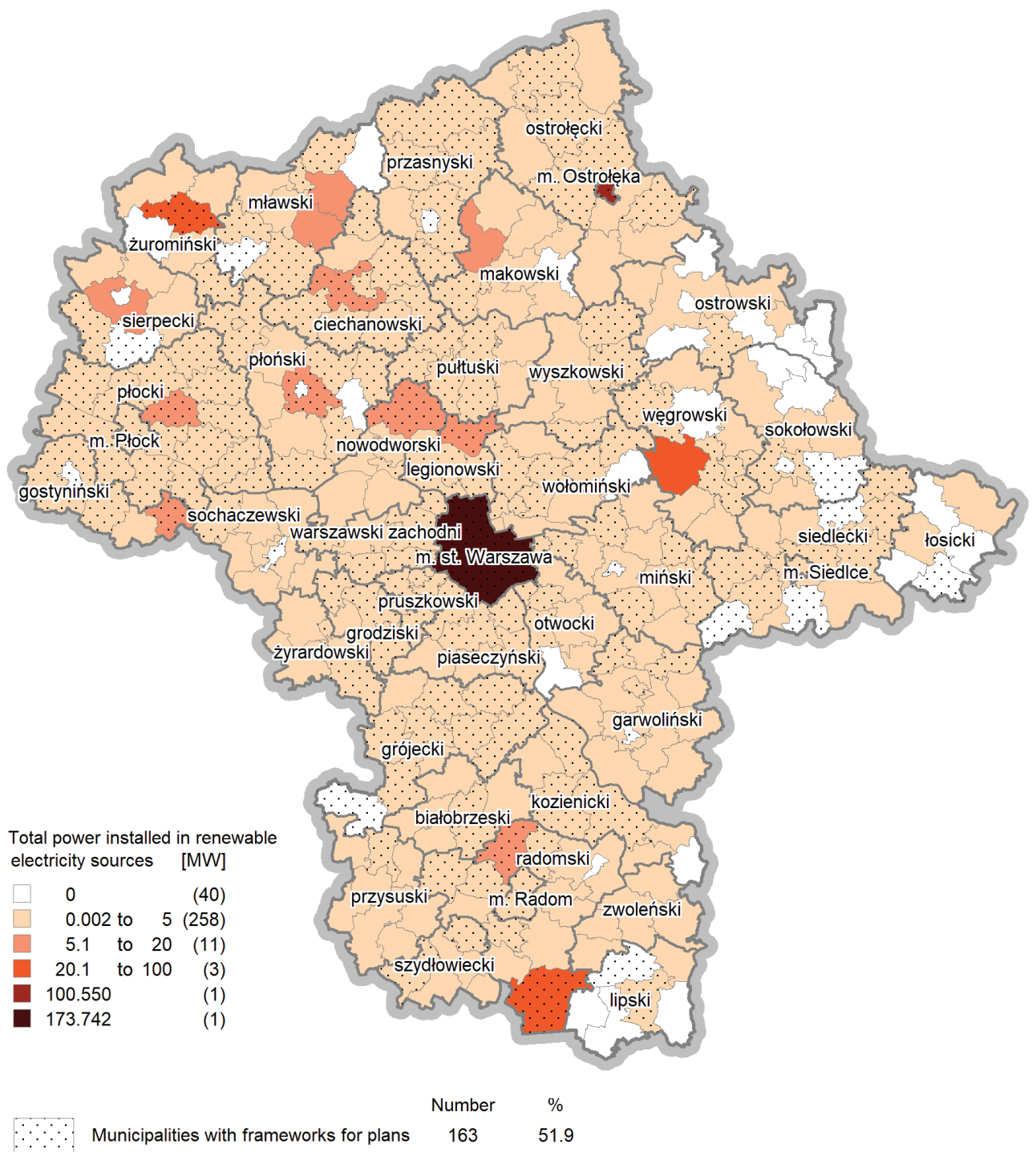

Fig. 6. Energy planning and exploitation of RES for the production of electricity in the municipalities of the Mazovia region as of 31.12.2017 Source: own work by MBPR based on information from energy companies 
In 2017, significant progress was visible in the spatial development of renewable sources of electricity, as the number of municipalities with their own sources of electricity connected to the national grid grew by 65 (from 209 to 274). Currently only 40 municipalities (12.7\%) have no such installations.

\section{Production and consumption of electricity in Mazovia and the remaining Polish regions (the region's power profile)}

According to data from the Polish Statistical Office (GUS), in 2006-2016 Mazovia was consistently third among Polish regions (after Łódzkie and Śląskie) in terms of the amount of electricity produced. In terms of use of such energy, Mazovia was second (after Śląskie, cf. Fig. 7). Mazovia occupies such a high place in production due to the presence of large national grid power plants: Kozienice and Ostrołęka and the Warsaw heat and power plants. The high energy usage is in turn the result of the economic, social, administrative and demographical potential of Mazovia which ranks first among Polish regions in terms of total GDP, GDP per capita, area and number of inhabitants.

The production and use of energy in absolute numbers do not fully reflect the region's power profile which is better illustrated by the ratio of energy produced and consumed. A ratio below $100 \%$ indicates that a region is not self-sufficient in terms of energy and needs to import electricity from other regions. Mazovia in 2016 was among such regions, ranking $7^{\text {th }}$ in the country with a ratio of $93.2 \%$. By the end of 2017, Mazovia's power profile had significantly improved, as a new power unit with a capacity of $1075 \mathrm{MW}$ begun to be exploited in the Kozienice power plant after testing. This will be reflected in statistical data for 2017 (which will be available by the end of 2018).

In the context of this paper, the most important indicator is the ratio of energy produced from RES to total energy consumption. Unfortunately, in this category Mazovia ranks $13^{\text {th }}$ in the country (Fig. 8) which shows that despite a large RES potential, its exploitation in the field of electricity production is far from satisfactory. In 2016 (data for 2017 was not yet available), the indicator was at around $5.5 \%$, much below the national average of $14.3 \%$. A troubling aspect is the fact that both the amount of energy produced from RES and its share in total consumption have been falling for several years (Fig. 9). This is an unwelcome tendency, as the high production of energy from coal in Mazovia places the region among the foremost producers of energy production-related greenhouse gases in Poland. 


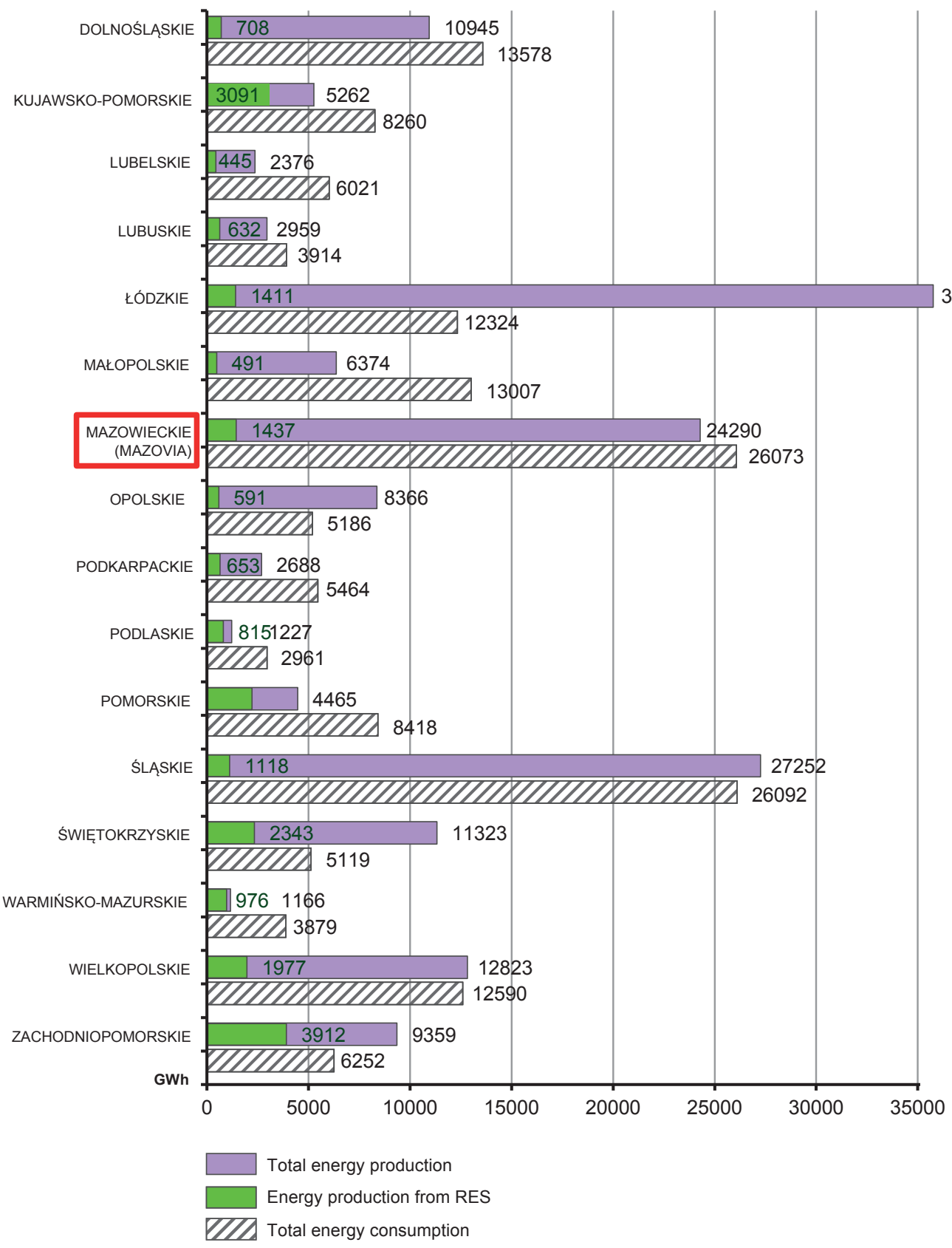

Fig. 7. Production and consumption of electricity in Polish regions in 2016

Source: own work by MBPR based on data from GUS (Local Data Bank) 


\section{RENEWABLE SOURCES OF ELECTRICITY IN THE MAZOVIA REGION \\ Zbigniew Cieszkowski}

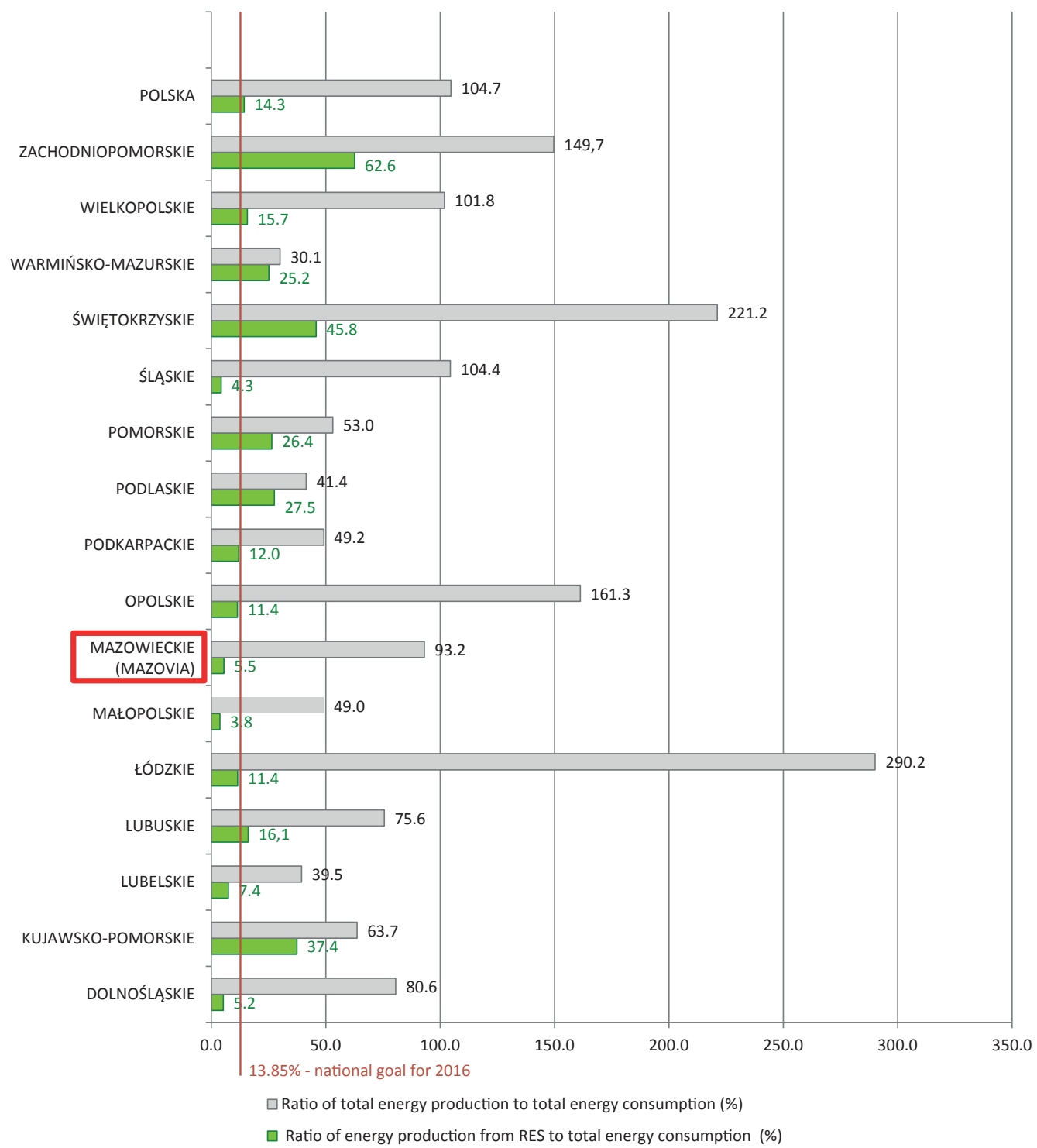

Fig. 8. Ratio of electricity production to consumption (\%) in Polish regions in 2016 Source: own work by MBPR based on data from GUS (Local Data Bank) 


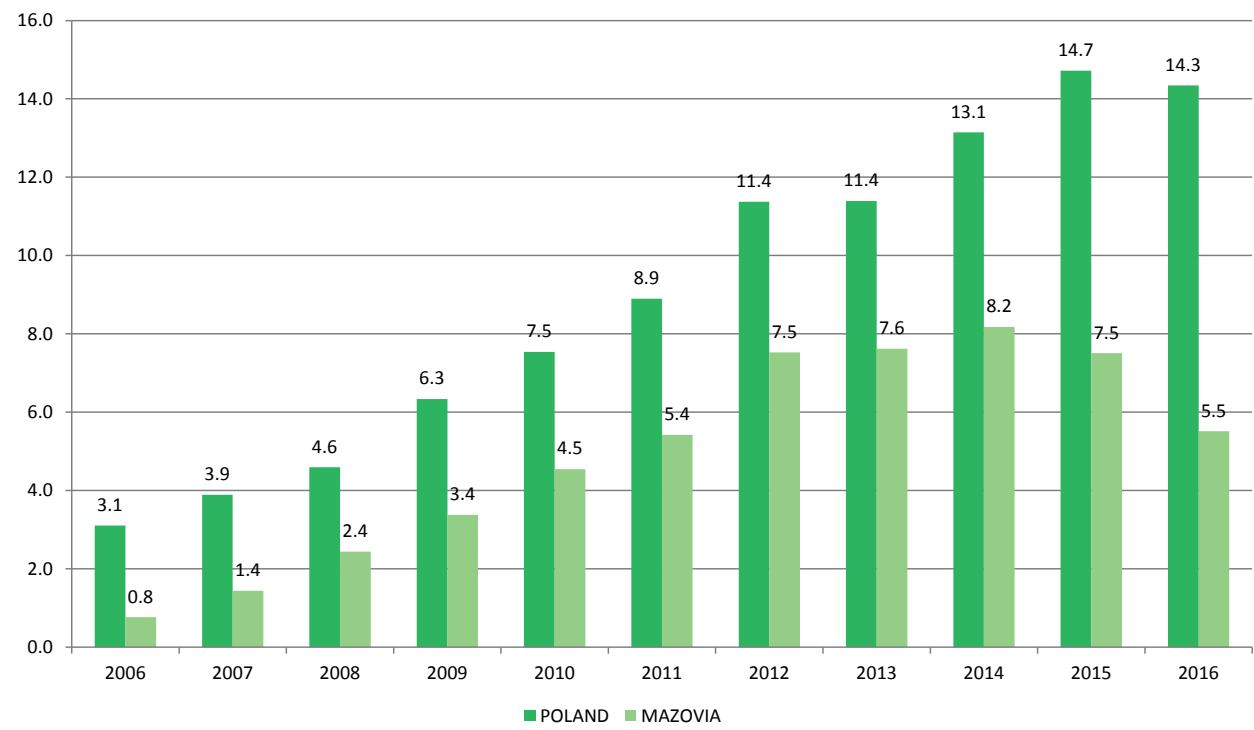

Fig. 9. Share of energy produced from RES in total energy consumption in Poland and Mazovia in 2006-2016

Source: own work by MBPR based on data from GUS (Local Data Bank)

\section{Development of renewable sources of electricity connected to the national energy grid in Mazovia in 2007-2017}

The effects of the development of renewable sources of electricity were analyzed on the basis of data collected directly by MBPR from companies active in Mazovia. The scope and structure of the data allowed for an analysis of the extent of development of three types of installations for the production of electricity from RES connected to the national grid. These types, according to the act on renewable sources of energy [Ustawa $z$ dnia 20 lutego $2015 \mathrm{r}$. o odnawialnych źródłach energii], are:

- microinstallations - with a total installed electric power capacity below $40 \mathrm{~kW}$,

- small installations - with a total installed electric power capacity of 40 to $200 \mathrm{~kW}$,

- installations with a total installed electric power capacity of over $200 \mathrm{~kW}$, which are not directly mentioned in the act, and will be referred to as large installations.

As far as microinstallations are concerned, a very important element of the act on renewable sources of energy is the introduction of a definition of a prosumer. A prosumer is defined as a final recipient buying electricity according to a comprehensive contract, producing electricity solely from RES through microinstallations, in order to use it for their own purposes, not related to economic activity as defined in the act on the freedom of economic activity. 
Tables 1 and 2 below present an overview of the renewable sources of electricity in Mazovia at the beginning and end of the period analyzed (2006-2017). At the end of 2006, there were only 23 installations with a total installed power capacity of $125.312 \mathrm{MW}$. By the end of 2017, their number had grown to 2835 (including 2668 prosumer microinstallations) with a total capacity of 718.890 MW. A 5.5-fold increase in the installed capacity in Mazovia (6.3-fold in Poland) resulted in an 8-fold increase in the production of electricity from RES (5.3-fold in Poland) according to GUS data.

Table 1. Sources of electricity from RES connected to the national energy grid in the Mazovia region as of 31.12 .2006

\begin{tabular}{|c|c|c|c|c|c|c|c|c|c|c|c|c|}
\hline \multirow[b]{3}{*}{ 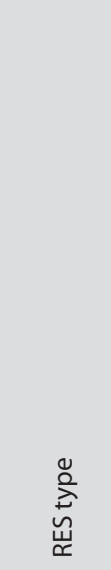 } & \multicolumn{9}{|c|}{ Installation scale } & \multirow[b]{3}{*}{ 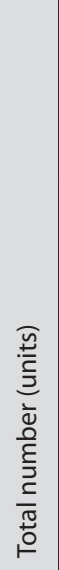 } & \multirow[b]{3}{*}{ 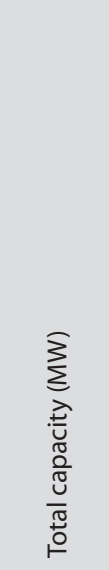 } & \\
\hline & \multicolumn{3}{|c|}{$\begin{array}{l}\text { Large installations } \\
\text { (over } 0.2 \mathrm{MW} \text { ) }\end{array}$} & \multicolumn{3}{|c|}{$\begin{array}{c}\text { Smal installations } \\
(0.04-0.2 \mathrm{MW})\end{array}$} & \multicolumn{3}{|c|}{$\begin{array}{l}\text { Microinstallations } \\
\text { (up to } 0.04 \mathrm{MW} \text { ) }\end{array}$} & & & \\
\hline & 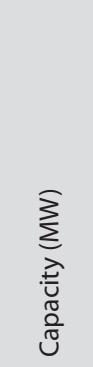 & 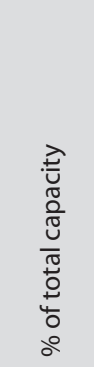 & 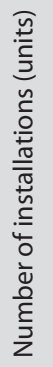 & 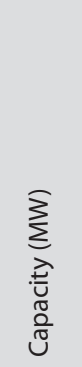 & 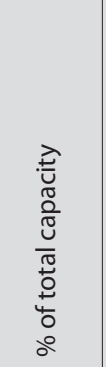 & 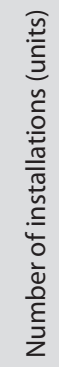 & 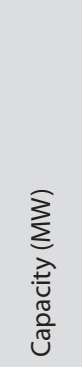 & 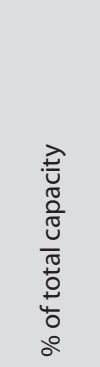 & 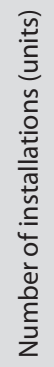 & & & 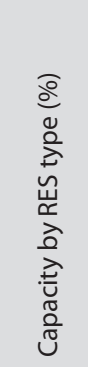 \\
\hline wind & 1.40 & 1.13 & 3 & 0.095 & 10.51 & 1 & 0 & 0.00 & 0 & 4 & 1.495 & 1.19 \\
\hline biomass & 100.00 & 80.46 & 1 & 0 & 0.00 & 0 & 0 & 0.00 & 0 & 1 & 100.000 & 79.80 \\
\hline water & 21.48 & 17.28 & 4 & 0.509 & 56.31 & 6 & 0.129 & 100.00 & 4 & 14 & 22.119 & 17.65 \\
\hline biogas & 1.39 & 1.12 & 2 & 0.300 & 33.19 & 2 & 0 & 0.00 & 0 & 4 & 1.698 & 1.36 \\
\hline solar & 0 & 0.00 & 0 & 0 & 0.00 & 0 & 0 & 0.00 & 0 & 0 & 0 & 0.00 \\
\hline TOTAL & 124.27 & 100.00 & 10 & 0.904 & 100.00 & 9 & 0.129 & 100.00 & 4 & 23 & 125.312 & 100.00 \\
\hline
\end{tabular}

Source: own work by MBPR based on information from energy companies

The production of energy from renewable sources in Mazovia grew in 2007-2014 and fell in 2015-2017. The fall was the result of a significant change in the support to the renewable energy sector which reduced the backing for the use of biomass in national grid power plants which (alongside wind energy) was one of the main elements of the renewable energy mix in Mazovia. Such a decrease was not visible in Poland as a whole as it was balanced by a faster growth of wind energy installations.

The changes in the installed capacity of renewable sources of electricity connected to the national power grid (Fig. 10) were supplemented with information on the development of individual types of RES since 1963 when the largest waterpower plant in the region (20 MW) 
began operation in Dębe. In the area of the current Mazovia region waterpower was the only source of renewable energy until 1999 when the first biogas plant was built. Several years later, in 2006, the Ostrołęka power plant began co-firing biomass with coal. In the same year the first four wind power installations were connected to the grid. In effect, at the beginning of 2007, electricity in Mazovia was produced from: waterpower, biogas, biomass and wind. The epoch of solar power began in 2010.

Table 2. Sources of electricity from RES connected to the national energy grid in the Mazovia region as of 31.12 .2017

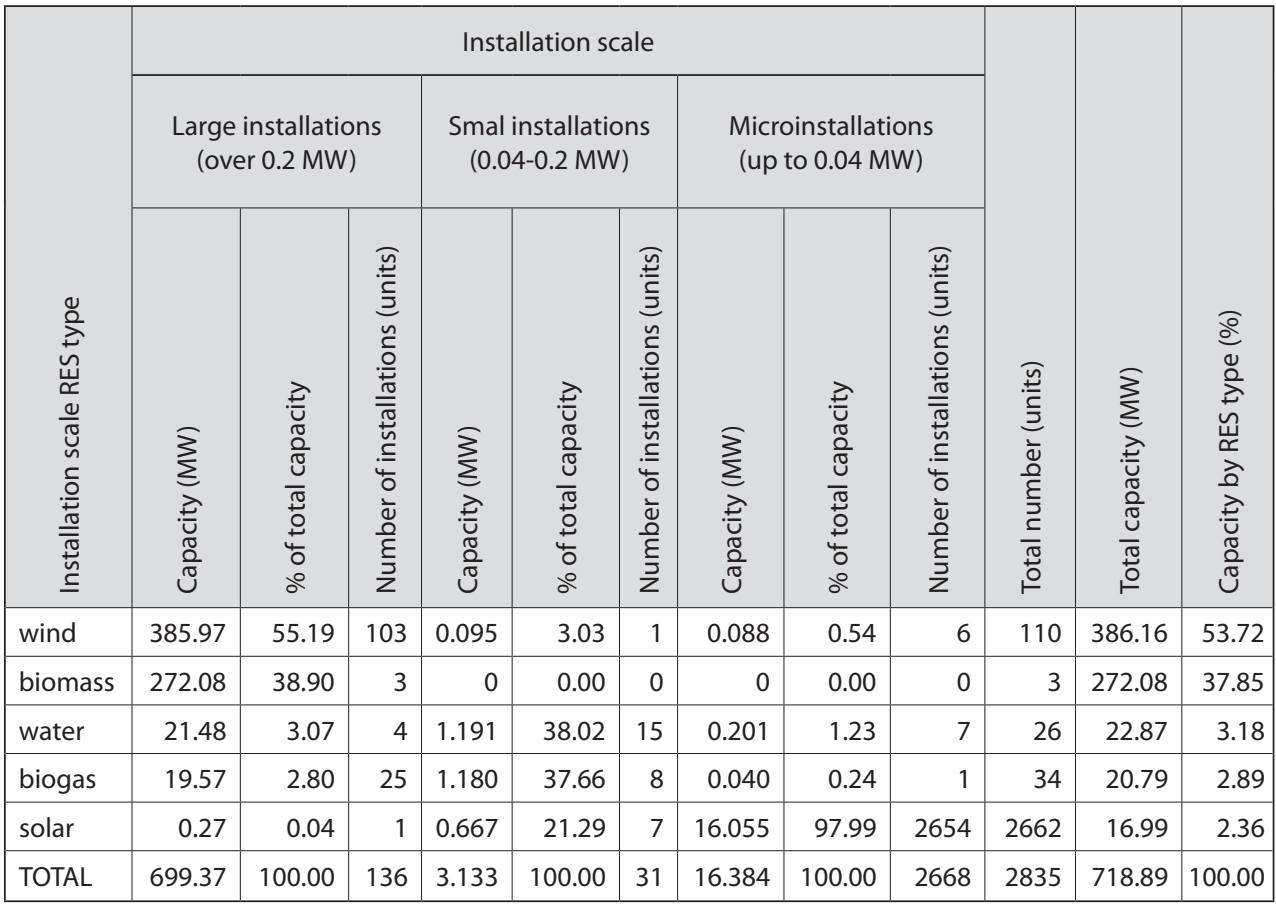

Source: own work by MBPR based on information from energy companies

At the end of 2017, the dominant type of renewable energy technology in the region was wind power (53.7\% of installed capacity). In second place was co-firing and biomass (37.9\%) and the remaining types were: water power $(3.2 \%)$, biogas $(2.9 \%)$, solar power $(2.3 \%)$. On a national scale, wind power is even more dominant $(68.4 \%)$, biomass accounts for $16.0 \%$, water for $11.5 \%$, biogas for $2.8 \%$ and solar power for $1.3 \%$. The total installed capacity of wind and biomass installations in Mazovia account for $91.6 \%$ of all RES power sources in the region. In Poland, they account for $84.4 \%$ with a significantly higher share of wind power.

In spatial terms, the highest concentration of small and large installations occurs in the northeastern and central parts of Mazovia (Fig. 11). Prosumer installations are, with the exception of a few eastern counties, distributed rather evenly throughout the region. 


\section{RENEWABLE SOURCES OF ELECTRICITY IN THE MAZOVIA REGION \\ Zbigniew Cieszkowski}

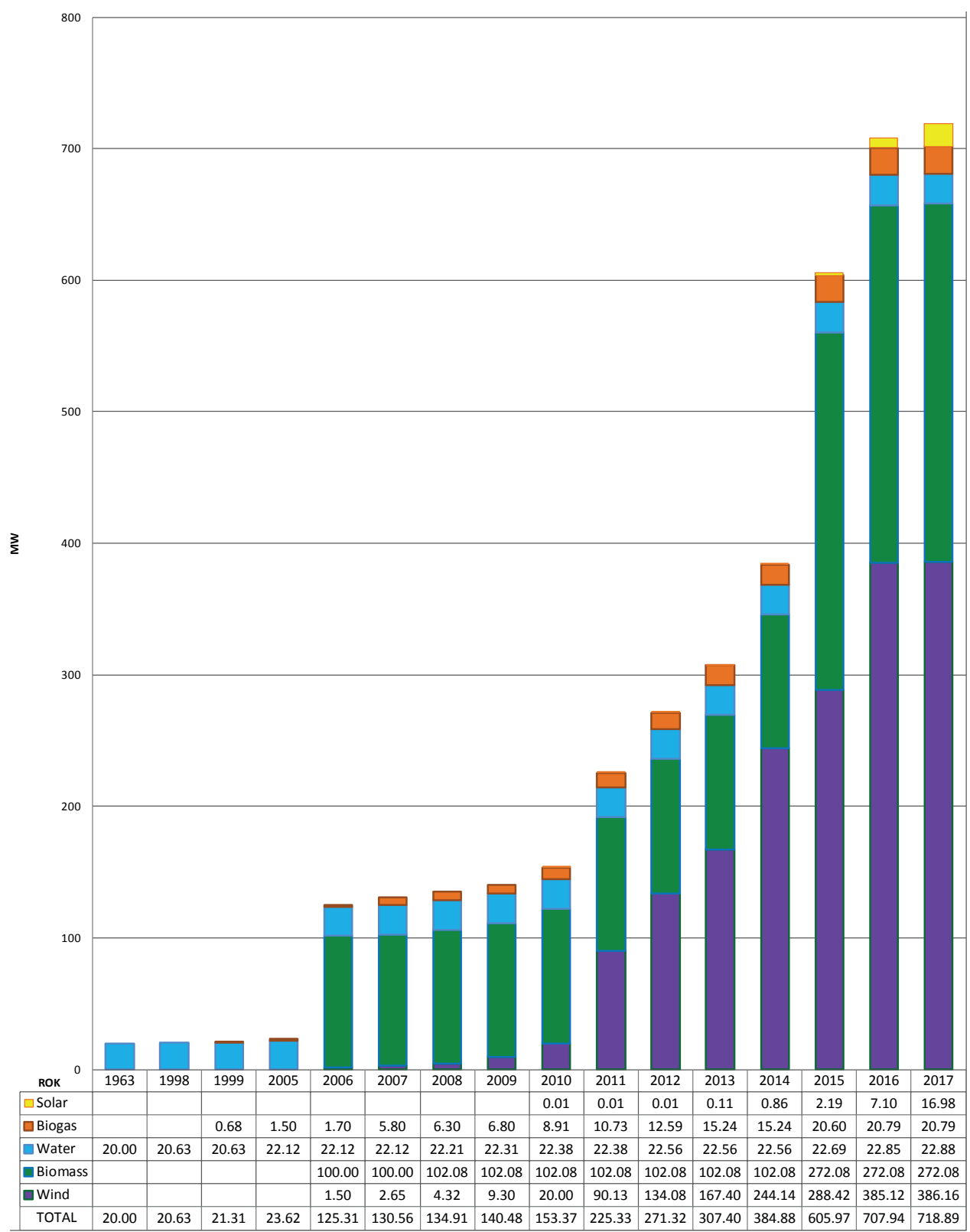

Fig. 10. Installed capacity of renewable sources of electricity in Mazovia connected to the National Power System in 1963-2017

Source: own work by MBPR based on information from energy companies 


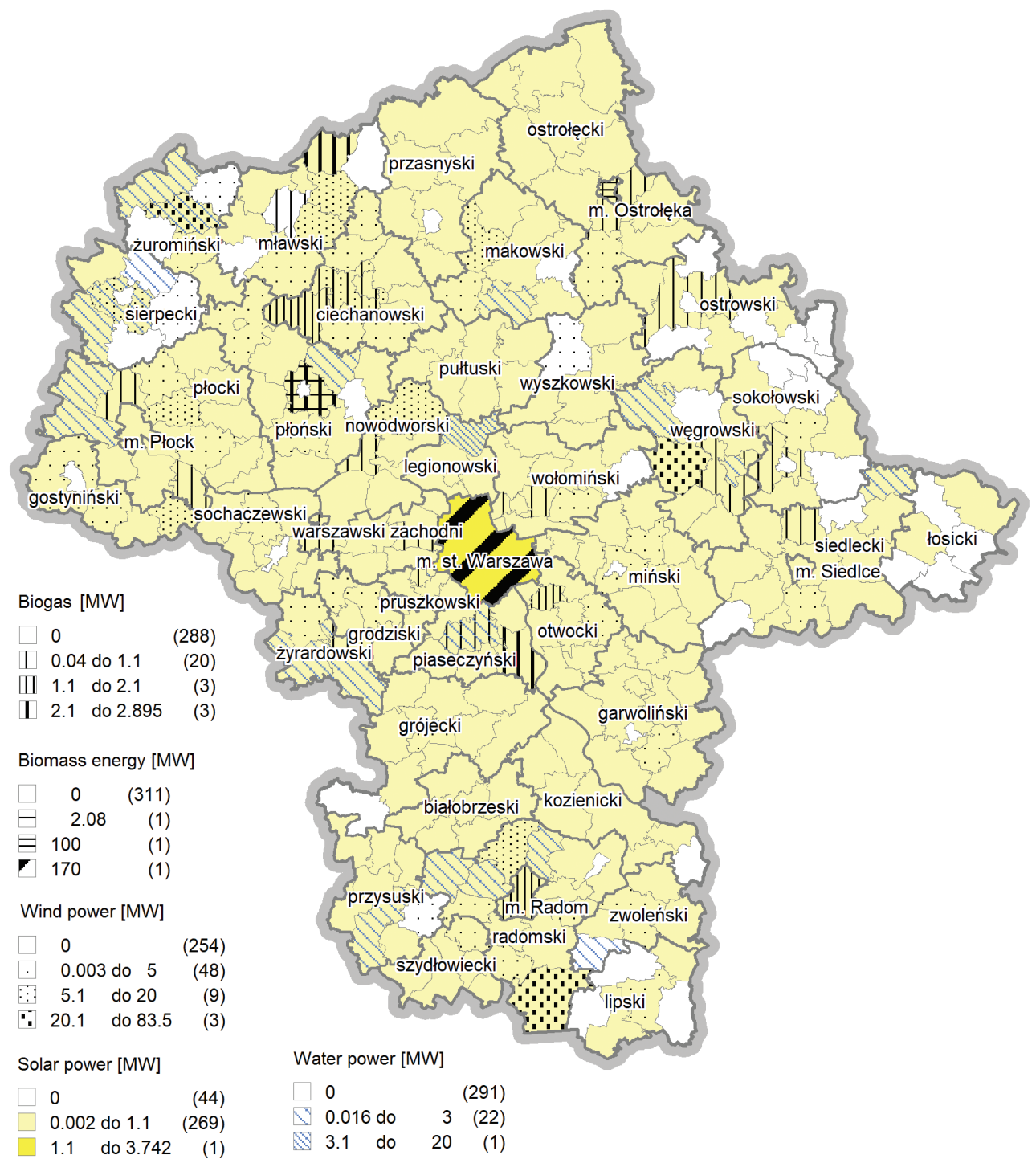

Fig. 11. Installed capacity of renewable sources of electricity connected to the National Power System in the municipalities of Mazovia as of 31.12.2017 Source: own work by MBPR based on information from energy companies 
Interesting results are provided by an analysis of the sources of renewable energy according to the installed capacity of individual types. At the beginning of 2007 (Table 1), 10 large installations (over $0.2 \mathrm{MW}$ ) accounted for over $99 \%$ of the total capacity of all renewable sources of electricity while 13 smaller installations accounted for the remaining less than 1\%. By the end of 2017 (Table 2), 136 installations of over $0.2 \mathrm{MW}$ accounted for $97.2 \%$ of the total installed capacity. 31 small installations and the microinstallations developing thanks to the support provided by the act on renewable sources of energy summed up to only a small share of the total power produced from renewable sources. However, they play an important role in improving local energy security on the level of municipalities, individual towns and villages and consumers. Despite the high expectations concerning the development of prosumer microinstallations, the results of the support of their development are not impressive in Mazovia: only 168 new microinstallations appeared in 2015, 728 in 2016 and 1668 in 2017. The share of the prosumer segment in the total capacity of RES-based electricity sources amounted to only $2.3 \%$ in 2017.

An analysis of RSEs by type and capacity shows that:

- among large installations the dominant sources of power are wind and biomass,

- among small installations the dominant sources of power are water and biogas, a new element is solar power,

- microinstallations make use almost exclusively of solar power, they are installed through the system of support for prosumer installations.

In general, the production of electricity from RES in Mazovia so far has been based on the development of high-capacity wind energy installations and the use of biomass in large national grid power plants (including co-firing). These two sources account for $87 \%$ of the electricity produced ( $86 \%$ in Poland as a whole). The remaining types of technology currently come up against such barriers to development as: high investment costs per unit of energy produced, problems with the storage of energy, impact on local electricity grids not adapted to unstable voltage sources.

Taking the above into account, high-capacity wind energy installations and biomass installations could have been perceived as the main chance for a significant increase in the share of renewable sources of electricity in the total consumption, in both Mazovia and Poland as a whole. However, the change of political stance towards RES by the new government practically deprived these technologies of opportunities for further development. As a result, a very large fall in the production of electricity through co-firing and from biomass took place in 2014-2016 and the majority of wind energy installations are at risk of becoming unprofitable. The results of such an inhibition of the development of RES technologies crucial from Mazovia's point of view are already visible, with the production of electricity from RES in 2016 at only $72.35 \%$ of the level achieved in the peak year of 2014 .

Paradoxically, 2015 and 2016 were still years of significant growth in the number of new wind energy installations as the investment process had started even five years earlier. In 2017 the development of wind power definitely slowed down, as only one new $1 \mathrm{MW}$ installation 
was activated. Among other types of RSEs (water, biomass, solar power), not a single small or large installation was activated. The only type which showed some growth were microinstallations. These, however, despite their large number $(2668$, with a total capacity of $16.348 \mathrm{MW}$ ) accounted for a negligible share (c. $0.5 \%$ ) in regional production of electricity from RES in 2017. From a spatial perspective, the county with the most microinstallations and the greatest total capacity is Warsaw (568 units - 3.165 MW). Six other counties have a total of over $0.5 \mathrm{MW}$ from $80-140$ installations. In the remaining parts of the region, the amounts of energy produced are, unfortunately, minute.

An important indicator of the effectiveness of electricity production from RES is the capacity utilization factor - the ratio (percentage) of the actual electricity output from a given installation over the year to its maximum possible output, assuming it would be working nonstop all year long at full capacity. The value of this indicator varies significantly, depending on type of RES technology, the atmospheric conditions, localization and the current support available for a given technology. For simple analyses, according to calculations based on GUS and URE (the Energy Regulatory Office) data, the average capacity utilization factor for wind energy installations is $22-24 \%$, for solar panels $9-11 \%$, for water power around $26 \%$, for biogas around $50 \%$. In the case of biomass, including co-firing, variations depend on economic

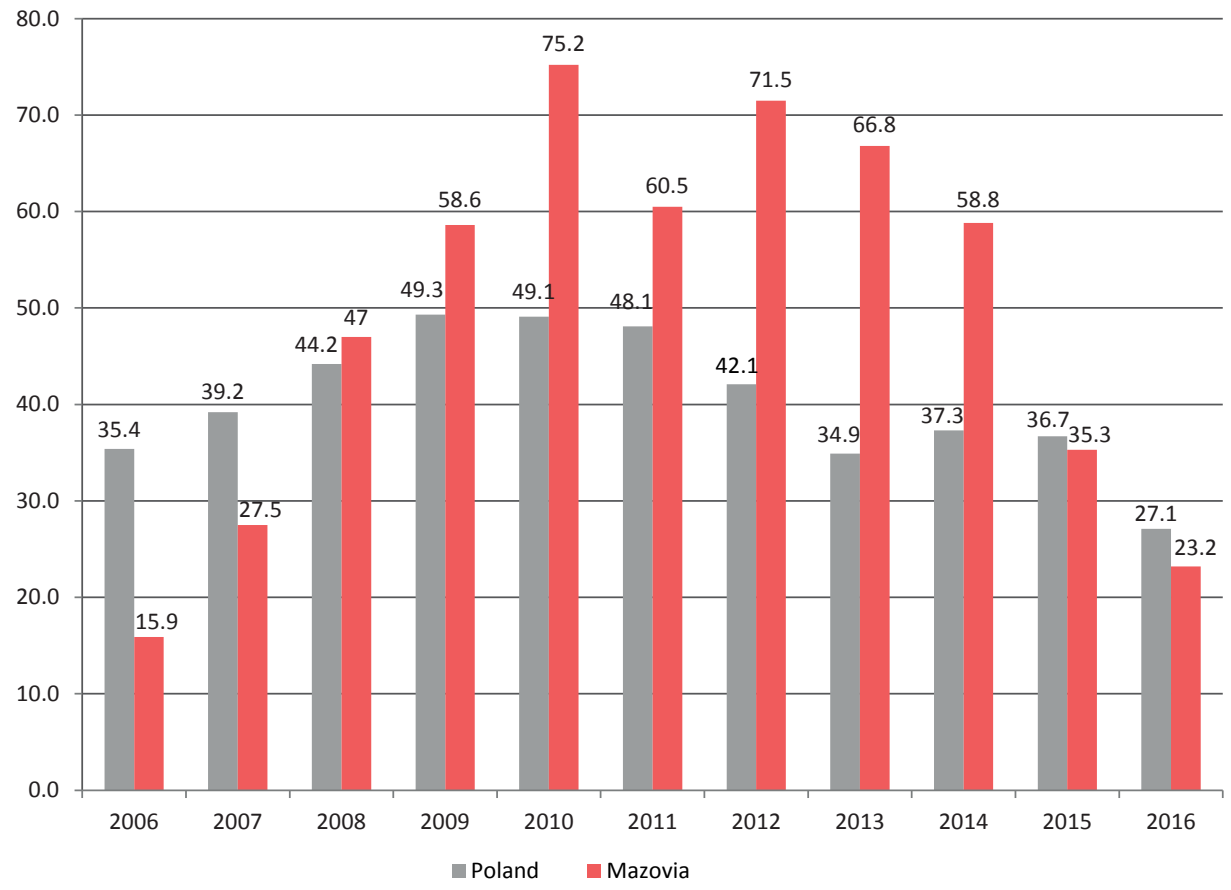

Fig. 12. RES capacity utilization factor in 2006-2016 Source: own work by MBPR based on data from GUS (Local Data Bank) 
and market conditions which influence the price at which biomass can be purchased and energy sold. A comparative analysis of the capacity utilization factor of all the RSEs in Poland and Mazovia (Fig. 12) indicates that in 2008-2014 Mazovia achieved significantly higher values than the national average. This correlates with the prevalence of biomass technology in our region as opposed to wind energy in Poland as a whole. 2015-2017 was a time of rapid decline in the use of biomass in national grid power plants which resulted in the value of the indicator falling to levels similar to those achieved in wind energy installations.

\section{RES development in Poland and Mazovia - opportunities and challenges}

New opportunities for the development of the Polish RES sector should arise from the European Union's climate and energy policy for the new programming period which entails new legal conditions. Another opportunity results from the diagnosed assets of renewable energy.

The new climate and energy package agreed upon at the EU summit in 2014 aims towards an even higher share of energy from renewable sources. By 2030 RES should account for $27 \%$ of the total energy consumption in the EU. This target has not yet been divided among member states.

In November 2017, the European Parliament's Environment, Public Health and Food Safety Committee proposed that the renewable energy target for 2030 be set at at least 35\% of gross energy consumption. In June 2018 the European Parliament and the Council of the European Union agreed upon a slightly lower level of $32 \%$, combined with obligatory national targets. This implies that 2020-2030 will be a very challenging period for Poland. Achieving a 15\% share in 2020 and a 32\% share by 2030 may be impossible in the context of the current Polish government's climate and energy policy.

The restrictions put upon the development of high-capacity renewable sources of electricity (wind farms, co-firing and use of biomass in national grid power plants) were, according to the legislator, to shift the focus of RES development to local dispersed energy sources making use primarily of solar power and biogas. Prosumer microinstallations were to play an important role. Hence, the terms "energy cluster" and "energy cooperative" defined in the Polish legal system as new legal and organizational entities intended to contribute to the transformation of the Polish energy market from a centralized system based on large power plants towards a decentralized local energy system accessible to local governments in legal and organizational terms.

From a technical, economic and organizational point of view, it will be difficult to fill the gap left in Mazovia after a significant decrease in (almost disappearance of) the production of electricity from co-firing and biomass with prosumer microinstallations as this would require creating around 310,000 such sources of electricity. This is a huge number when compared to the existing 2668 which suggests that microinstallations in Mazovia (and Poland) can be a supplement to the renewable energy sources rather than its basis. 
New approaches towards the organization of the local energy market have already started to be implemented in Poland and Mazovia. In May 2018, the Ministry of Energy granted 33 Certificates of Pilot Energy Clusters throughout the country, of which 5 were granted to clusters in Mazovia (in the przysuski and siedlecki counties and in the cities of Siedlce, Sokołów Podlaski and Sochaczew).

The Regional Government of Mazovia has recognized the significance of this sector of energy production and is currently conducting studies concerning the social, economic and infrastructural conditions of creating "autonomous energy regions" (ARE) in Mazovia. ARE are not yet strictly defined. Judging by the solutions applied in other European countries, ARE may be described as areas administered by local governments where they realize their own, independent energy policy according to their own development strategy. Energy is produced from local resources (not only renewable ones) and local production facilities. Production should be oriented towards satisfying the energy needs of all the recipients in a given ARE.

\section{Conclusion}

The implementation of European Union climate and energy policy in Poland is the sum of all the energy-related activities on the national, regional and local levels. The Mazovian Office for Regional Planning, has compiled an extensive database concerning energy, including RES, through studies and prognoses in various fields conducted for the Regional Government of Mazovia in order to fulfill its legal obligations concerning preparing regional strategic, planning and programming documents and energy planning.

All the analyzed regional strategic and programming documents are consistent with the European and Polish goals and activities concerning the protection of the climate and environment. Subsequent editions of Mazovia's development strategy and spatial development plan, along with programming documents, served as the basis for the development of a new, environment-friendly energy infrastructure based to a significant extent on RES. Among the most important activities of the regional government were also the preparation and implementation of operational programs contributing to a modern, ecological energy system: RPO WM 2007-2013 and RPO WM 2014-2020. Furthermore, the regional government paid attention to executing the regional environmental and energy policy when fulfilling the obligations put upon it by the Energy Law [Ustawa z dnia 10 kwietnia 1997 r. Prawo energetyczne] by issuing opinions on municipal energy planning documents, energy companies' development plans and their applications for concessions from the Energy Regulatory Office (Urząd Regulacji Energetyki) concerning the production, transmission and distribution of fuels and energy. In order for these tasks to be realized (since 2007, by the Mazovian Office for Regional Planning), constant cooperation is required with the Energy Regulatory Office, local governments and energy companies. In 2007-2017 the Regional Government of Mazovia issued opinions concerning 879 draft documents of importance to the development of energy production and transmission in the region. 
The conducted analyses have shown that Mazovia, as the largest region in Poland in terms of area, population and GDP, is also among the largest Polish producers (3rd place) and consumers (2nd places) of electricity. The region has significant assets of renewable energy which - if effectively used - could also place it high in the ranking of producers of ecological energy. In practice, the results of exploiting RES in the analyzed period of 20072017, are as follows:

- the amount of electricity produced from RES in Mazovia grew significantly (over 11fold) in 2007-2014, to fall in 2015-2017 due to changes in the national RES policy; in 2008-2014 the main source of electricity from RES was biomass, including co-firing, in 2015-2017 the share of biomass fell and in effect wind power became the main contributor,

- among Polish regions, Mazovia advanced in terms of production of energy from RES from $10^{\text {th }}$ place in 2007 to $3^{\text {rd }}$ in 2013, to fall back to $6^{\text {th }}$ in 2015 and 2016,

- in terms of the share of energy obtained from RES in total energy consumption, Mazovia ranked $11^{\text {th }}$ to $13^{\text {th }}$, with values of $0.8 \%$ in $2006,8.2 \%$ in $2013,7.5 \%$ in 2015 and $5.5 \%$ in 2016; a definite decline in the production of electricity from RES is visible and, in effect, the region's role in fulfilling the RES climate and energy goal is diminishing,

- the structure of RES used to produce electricity in Mazovia, based mostly on biomass and wind power, was less diversified than in Poland as a whole, where water power has a higher share,

- the total capacity of RES power sources connected to the national energy grid in Mazovia grew 5.7 times (from 125 to $719 \mathrm{MW}$ ), in Poland - 6.3 times (from 1362 to $8564 \mathrm{MW})$,

- in 2017 wind turbines accounted for $53.7 \%$ of the capacity of RES power in Mazovia, biomass, including co-firing, for $37.9 \%$ and the remaining RES for $8.4 \%$; in Poland, respectively, $68.4 \%, 16.0 \%$ and $11.5 \%$ (water power),

- in the category of prosumer microinstallations, solar power was practically the only type of installation; in 2017 such installations accounted for $2.3 \%$ of the RES capacity and only c. $0.5 \%$ of the production of green energy.

In general, the results of the analyses show that the revolutionary changes introduced in 2015-2016 to the RES support system and location rules for wind energy installations resulted in a significant nation-wide decline in the rate of development of high-capacity wind energy and biomass, including co-firing, installations. These RES types were of crucial importance to the share of ecological energy produced in Poland. Mazovia was particularly affected, as both types accounted for around 93\% of renewable energy production in 2015 and $87 \%$ in 2016. Paradoxically, Mazovia - which has the RES potential and assets allowing for a c. $20 \%$ share of energy from renewable sources - achieved a level of only $5.5 \%$ in 2016.

In practice, the implementation of the legal changes introduced in 2015-2016 to RES regulations showed that the remaining types of RES (water power, biogas, solar power, which can be used to develop small local installations and prosumer microinstallations) aren't able to fill the gap left by the blockage of development of high-capacity wind and 
biomass energy. Basing the development of RES on small and microinstallations requires enormous investments, the costly development of modern energy storage technology and a fundamental transformation of the technical and organizational structure of the centralized energy system towards a network of clusters, energy cooperatives and a maximum energy autonomy among municipalities and counties. In Poland, such a state could be achieved in the perspective of 2030-2050.

Another change was introduced to the regulations concerning the development of RES due to the significant risk of not achieving the 15\% target of energy from RES in total energy consumption by 2020 and the need to adapt national law to the European Union regulations concerning state aid. An act from mid-2018 modifies the law on RES [Ustawa $z$ dnia 7 czerwca 2018 r. o zmianie ustawy o odnawialnych źródłach energii oraz niektórych innych ustaw] and introduces a number of changes - necessary in terms of European law and postulated by producers of energy from RES. The most important changes are:

- the introduction of new rules concerning combining different types of aid,

- a change in the regulations concerning local biomass,

- a return to more favorable to investors tax regulations concerning wind farms,

- prolongation of validity of not yet realized wind farm building permits and a conditional permission for the renovation of existing installations;

- an increase in the volume of energy from RES subject to auction in 2018,

- introducing feed-in tariffs for biogas and hydropower plants,

- increasing the competitiveness of the auction system through new mechanisms,

- facilitating participation in auctions concerning offshore wind power,

- increasing the maximum capacity of microinstallations (from 40 to $50 \mathrm{~kW}$ ) and small installations (from 200 to $500 \mathrm{~kW}$ ) and facilitating their connection to the network as well as obtaining support for small installations.

Experts and participants of the RES energy market agree that the changes introduced by the act focus mainly on fixing the previous faulty regulations and implementing the required EU solutions concerning state aid. However, the act is considered not to include the expected fundamental reconstruction of the Polish renewable energy sector. A common opinion is that the legislator introduced only the necessary minimum of changes necessary to achieve the EU RES targets by 2020 while postponing a more profound revision of the system indefinitely. The main problem of the current government's energy policy is the focus on protecting the Polish coal energy sector from the EU decarbonization policy. Such a stance will continue to be the reason for political conflicts between Poland and the EU as well as disputes and discussions within the country. 


\section{References \\ Legal acts and documents}

Krajowy plan działania w zakresie energii ze źródeł odnawialnych - document adopted by the Council of Ministers on December $7^{\text {th }}, 2010$.

Krajowy Plan rozwoju mikroinstalacji odnawialnych źródeł energii do roku 2030, Instytut Energetyki Odnawialnej, Warszawa, 2015.

Określenie potencjału energetycznego regionów Polski w zakresie odnawialnych źródeł energii wnioski dla Regionalnych Programów Operacyjnych na okres programowania 2014-2020, Instytut Energetyki Odnawialnej, commissioned by Ministerstwo Rozwoju Regionalnego, Warszawa, 2014.

Plan zagospodarowania przestrzennego województwa mazowieckiego - Act No. 65/2004 14 of the Regional Assembly of the Mazovia Region of June 7th 2004 (Dz.Urz. Woj. Maz. nr 217, poz., 5811).

Plan zagospodarowania przestrzennego województwa mazowieckiego - Act No. 180/14 of the Regional Assembly of the Mazovia Region of July 7, 2014 (Dz.Urz. Woj. Maz. z 2014 r., poz. 6868).

Program możliwości wykorzystania odnawialnych źródeł energii dla Województwa Mazowieckiego, Act No. 208/06 of the Regional Assembly of the Mazovia Region of October ${ }^{\text {th }}, 2006$.

Rozwój energetyki opartej na źródłach odnawialnych w województwie mazowieckim -stan i wyzwania, 2015, Mazowsze. Analizy i Studia, 44, MBPR,Warszawa.

Strategia rozwoju województwa mazowieckiego do 2030 roku. Innowacyjne Mazowsze - Act No. 158/13 of the Regional Assembly of the Mazovia Region of October 28 ${ }^{\text {th }}, 2013$.

Strategia rozwoju województwa mazowieckiego do roku 2020 - Act No. 78/06 of the Regional Assembly of the Mazovia Region of May 29 ${ }^{\text {th }}, 2006$ (Dz.Urz. Woj. Maz. nr 139, poz. 4590).

Ustawa z dnia 10 kwietnia 1997 r. Prawo energetyczne (Dz.U. z 2018 r., poz. 755 z późn. zm.).

Ustawa z dnia 20 maja 2016 r. o inwestycjach w zakresie elektrowni wiatrowych (Dz.U. z 2016 r., poz. 961).

Ustawa z dnia 22 czerwca 2016 r. o zmianie ustawy o odnawialnych źródtach energii oraz niektórych innych ustaw (Dz.U. z 2016 r., poz. 925).

Ustawa z dnia 7 czerwca 2018 r. o zmianie ustawy o odnawialnych źródłach energii oraz niektórych innych ustaw (Dz.U. z 2018 r., poz. 1276). 


\section{Webpages}

Mazovian Energy Agency, http://www.mae.com.pl/

National Statistical Office, http://www.stat.gov.pl/

Energy Regulatory Office, http://www.ure.gov.pl/

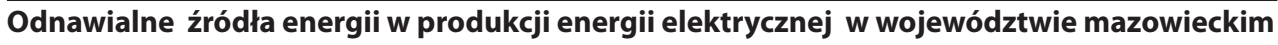

\section{STRESZCZENIE}

Artykuł poświęcono problematyce rozwoju wykorzystania odnawialnych źródeł energii do produkcji energii elektrycznej w województwie mazowieckim. Do analiz przyjęto okres lat 2007-2017 wykorzystując zaktualizowane opracowanie własne MBPR z 2015 r. pt. Rozwój energetyki opartej na źródłach odnawialnych w województwie mazowieckim stan i wyzwania. Część analityczną artykułu poprzedzono informacjami o zdiagnozowanych zasobach OZE w regionie oraz jego obszarach predestynowanych do rozwoju elektroenergetyki odnawialnej. W skondensowanej formie omówiono formalnoprawne uwarunkowania rozwoju i wykorzystania OZE, a także efekty wynikających z nich działań planistycznych, organizacyjnych samorządu województwa mazowieckiego oraz samorządów gminnych. Dokonano analiz danych statystycznych publikowanych przez GUS i danych uzyskanych od przedsiębiorstw energetycznych. Omówiono zagadnienia dotyczące produkcji oraz zużycia energii elektrycznej w woj. mazowieckim na tle regionów kraju oraz rozwój źródeł energii elektrycznej z OZE przyłączonych w regionie do krajowych sieci elektroenergetycznych.

Słowa kluczowe: odnawialne źródła energii, zasoby, polityka klimatyczno-energetyczna, Krajowy System Energetyczny (KSE), energetyka wiatrowa, biomasa, biogaz, hydroenergetyka, fotowoltaika, geotermia, prosument

MSc Eng. Zbigniew Cieszkowski - specialist in electric power engineering and renewable energy sources, employee of the Siedlce Branch of the Mazovian Office for Regional Planning.

mgr inż. Zbigniew Cieszkowski - specjalista w zakresie elektroenergetyki oraz zagadnień zwiqzanych z rozwojem odnawialnych źródeł energii, pracownik Oddziału Terenowego w Siedlcach Mazowieckiego Biura Planowania Regionalnego w Warszawie. 